\title{
Socio-Economic Analysis of Soybean Farmers in South Sulawesi Province
}

\author{
Hendrik Gunadi \\ Faculty of Economic,Universitas Kristen Indonesia Paulus, Makassar, Indonesia \\ \{hendrik_gunadi@ukipaulus.ac.id\}
}

\begin{abstract}
South Sulawesi is one of the provinces in Indonesia which contributes $6.6 \%$ to national soybean production. Soybean productivity in South Sulawesi is on average above the national soybean productivity. However, soybean farmers have not been able to draw many benefits from the high productivity because in general they are soybean farmers for consumption purposes. This study aims to look at opportunities to increase the income of soybean farmers through the change from consumption farmers to soybean breeder farmers. The method used in this study is a business feasibility analysis by calculating the $\mathrm{R} / \mathrm{C}$ ratio and $\mathrm{B} / \mathrm{C}$ ratio, social capital in the form of social networks of farmers on the West Coast and East Coast of South Sulawesi, and climate mapping using ArcGis 10.5. The results showed that the feasibility of soybean business in the West Coast of South Sulawesi for breeders and consumption farmers each had an R/C ratio of 2.33 and 1.33 , while the $\mathrm{B} / \mathrm{C}$ ratios were 1.72 and 0.72 . The soybean business on the East Coast of South Sulawesi for breeders and consumption farmers each had an $\mathrm{R} / \mathrm{C}$ ratio of 2.25 and 1.63 , while the $\mathrm{B} / \mathrm{C}$ ratio were 1.25 and 0.63 . Social capital in the form of a social network between the West Coast and the East Coast has the potential to be developed into a network of soybean breeder that produce continuous (based on unique climate) in South Sulawesi.
\end{abstract}

Keywords: breeder; consumption; social capital; climate

\section{Introduction}

South Sulawesi is one of the provinces in Indonesia which contributes $6.6 \%$ of the national soybean production. Soybean productivity in South Sulawesi averaged 1.7 tons/ha above the national soybean productivity which reached 1.5 tons/ha. However, this high productivity is not accompanied by a good selling price and marketing network, so farmers are usually reluctant to plant soybeans. Usually only soybean farmers keep planting soybeans because the selling price is still quite high, but this is not the case with consumption farmers [1].

South Sulawesi as the $6^{\text {th }}$ soybean producer (after East Java, Central Java, West Java, West Nusa Tenggara, and Aceh) has a natural gift in the form of the East Coast and West Coast, so that despite weather changes that may be very extreme in one region, opportunities other regions in producing large enough soybean seeds. Climate change in South Sulawesi on the West and East Coast, especially the availability of sufficient water is very influential on the productivity of soybean plants [2] - [3]. The area of soybean planting in South Sulawesi is 
only $37,128 \mathrm{Ha}$, but with its unique climate, which is the rainy season and the dry season side by side and alternating between the west coast and the east coast allows soybean production to be continuous throughout the year [4].

Social capital are parts of social organizations such as beliefs, norms, value, sense of belonging, and networks that can improve community efficiency. [5] Social capital can also be seen in the perspective of bonding, bridging, and linking. As the bonding of social capital refers to the relationship of trust and cooperation between members of the network who are similar in a sociodemographic, and with high trust. As a bridge of social capital refers to the relationship between large networks to collaborate and coordinate with smaller networks, and with lower trust. As a linking of social capital refers to the norms of respect and trusting relationships between people who interact [6]. The social capital bond as a fellow soybean breeder and as a resident of the same province will be a close bond in an effort to keep all members of the breeder organization to be always connected with each other and can help each other for the welfare of fellow breeders in South Sulawesi.

\section{Method}

The study was conducted in Maros and Takalar District (representing the West Coast) and Soppeng and Bone District (representing the East Coast). The selection of sample areas is done by purposive sampling which is a soybean producing district. For soybean productivity data, field trials and interviews with soybean growers are conducted. To analyze the soybean breeding business used calculation of the farming business that is the Return Cost Ratio (R/C) and Benefit Cost Ratio (B/C) [7] - [8]. For social capital, an analysis of social networks is carried out by making a network map (sociogram) [9]. Meanwhile, to maintain the continuity of production, an analysis of monthly rainfall maps was carried out for 30 years (1981-2010).

\section{Results and Discussion}

\subsection{Farming Business Analysis}

To determine the feasibility of soybean farming, an $\mathrm{R} / \mathrm{C}$ and $\mathrm{B} / \mathrm{C}$ ratio was calculated from the costs and receptions of soybean farming in the West and East Coasts of South Sulawesi as in Table 1 and Table 2.

Table 1. Business Analysis of Soybean Breeding on the West Coast of South Sulawesi

\begin{tabular}{|c|c|c|c|c|c|c|c|c|c|}
\hline \multirow[b]{2}{*}{$\begin{array}{l}\mathbf{N} \\
\mathbf{0}\end{array}$} & \multirow[b]{2}{*}{ Description } & \multicolumn{4}{|c|}{ Breeding } & \multicolumn{4}{|c|}{ Consumption } \\
\hline & & $\begin{array}{c}\text { Number } \\
\text { of }\end{array}$ & Unit & Price & Value & $\begin{array}{c}\text { Numbe } \\
\text { r of }\end{array}$ & Unit & Price & Value \\
\hline I. & Cost of Prod & ction Facili & & & & & & & \\
\hline 1 & Seeds & 50 & $\mathrm{Kg}$ & 15.000 & 750.000 & 50 & $\mathrm{Kg}$ & 8.000 & 400.000 \\
\hline 2 & $\begin{array}{l}\text { NPK } \\
\text { Phonska }\end{array}$ & 250 & $\mathrm{Kg}$ & 2.500 & 625.000 & 250 & $\mathrm{Kg}$ & 2.500 & 625.000 \\
\hline 3 & Pesticide & 3 & Bottle & 50.000 & 150.000 & 3 & Bottle & $\begin{array}{c}50.00 \\
0\end{array}$ & 150.000 \\
\hline II. & $\begin{array}{l}\text { Labor costs } \\
\text { Land }\end{array}$ & & & & & & & & \\
\hline 1 & preparation & 1 & $\mathrm{Ha}$ & 500.000 & 500.000 & & $\mathrm{Ha}$ & & \\
\hline 2 & Planting & 15 & HOK & 70.000 & $\begin{array}{c}1.050 .00 \\
0\end{array}$ & 15 & HOK & $\begin{array}{c}70.00 \\
0\end{array}$ & $\begin{array}{c}105.000 \\
0\end{array}$ \\
\hline
\end{tabular}




\begin{tabular}{|c|c|c|c|c|c|c|c|c|c|}
\hline \multirow[b]{2}{*}{$\begin{array}{l}\mathbf{N} \\
\mathbf{0}\end{array}$} & \multirow[b]{2}{*}{ Description } & \multicolumn{4}{|c|}{ Breeding } & \multicolumn{4}{|c|}{ Consumption } \\
\hline & & $\begin{array}{c}\text { Number } \\
\text { of }\end{array}$ & Unit & Price & Value & $\begin{array}{c}\text { Numbe } \\
\mathbf{r} \text { of }\end{array}$ & Unit & Price & Value \\
\hline 3 & Weeding & - & HOK & - & - & - & HOK & - & - \\
\hline 5 & Fertilizing & 4 & $\mathrm{HOK}$ & 70.000 & 280.000 & 4 & $\mathrm{HOK}$ & $\begin{array}{c}70.00 \\
0\end{array}$ & 280.000 \\
\hline 6 & Irrigation & 1 & $\mathrm{HOK}$ & 70.000 & 70.000 & 1 & $\mathrm{HOK}$ & $\begin{array}{c}70.00 \\
0\end{array}$ & 70.000 \\
\hline 7 & $\begin{array}{l}\text { Control of } \\
\text { HPT }\end{array}$ & 2 & $\mathrm{HOK}$ & 70.000 & 140.000 & 2 & $\mathrm{HOK}$ & $\begin{array}{c}70.00 \\
0\end{array}$ & 140.000 \\
\hline 8 & Harvest & 15 & $\mathrm{HOK}$ & 70.000 & $\begin{array}{c}1.050 .00 \\
0\end{array}$ & 15 & HOK & $\begin{array}{c}70.00 \\
0\end{array}$ & $\begin{array}{c}1.050 .0 \\
00\end{array}$ \\
\hline 9 & $\begin{array}{l}\text { Drying and } \\
\text { Threshing }\end{array}$ & 15 & $\mathrm{HOK}$ & 70.000 & $\begin{array}{c}1.050 .00 \\
0\end{array}$ & 15 & $\mathrm{HOK}$ & $\begin{array}{c}70.00 \\
0\end{array}$ & $\begin{array}{c}1.050 .0 \\
00\end{array}$ \\
\hline $\begin{array}{l}1 \\
0\end{array}$ & $\begin{array}{l}\text { Selection } \\
\text { and } \\
\text { Packaging }\end{array}$ & 5 & HOK & 70.000 & 350.000 & & & & \\
\hline III. & Additional costs & & & & & & & & \\
\hline 1 & $\begin{array}{l}\text { Administrati } \\
\text { on }\end{array}$ & 2 & Time & 7.500 & 15.000 & & & & \\
\hline 2 & Label & 75 & Unit & 200 & 15.000 & & & & \\
\hline 3 & Plastic Bags & 75 & Unit & 2.000 & 150.000 & & & & \\
\hline 4 & Rent of land & 1 & $\mathrm{Ha}$ & 1.000 .000 & $\begin{array}{c}1.000 .00 \\
0\end{array}$ & 1 & $\mathrm{Ha}$ & $\begin{array}{l}1.000 \\
.000\end{array}$ & $\begin{array}{c}1.000 .0 \\
00\end{array}$ \\
\hline $5 \quad \mathrm{I}$ & $\begin{array}{l}\text { Interest at a } \\
\text { cost }\end{array}$ & & & & 287.800 & & & & 232.600 \\
\hline $\begin{array}{l}\text { IV. } \\
\text { Produ }\end{array}$ & $\begin{array}{l}\text { Seed } \\
\text { uction }\end{array}$ & 1.450 & $\mathrm{Kg}$ & 12.000 & $\begin{array}{c}17.400 .0 \\
00\end{array}$ & 1.600 & $\mathrm{Kg}$ & 6.500 & $\begin{array}{c}10.400 \\
000\end{array}$ \\
\hline V. & Total costs & & & & $\begin{array}{c}7.482 .80 \\
0\end{array}$ & & & & $\begin{array}{c}6.047 .6 \\
00\end{array}$ \\
\hline VI. & Reception & & & & $\begin{array}{c}9.917 .20 \\
0\end{array}$ & & & & $\begin{array}{c}4.352 .4 \\
00\end{array}$ \\
\hline VII. & $\mathrm{R} / \mathrm{C}$ & & & & 2,33 & & & & 1,72 \\
\hline VIII. & $\mathrm{B} / \mathrm{C}$ & & & & 1,33 & & & & 0,72 \\
\hline
\end{tabular}

Table 2. Business Analysis of Soybean Breeding on the East Coast of South Sulawesi

\begin{tabular}{|c|c|c|c|c|c|c|c|c|c|}
\hline \multirow[b]{2}{*}{$\begin{array}{l}\mathbf{N} \\
\mathbf{0}\end{array}$} & \multirow[b]{2}{*}{ Description } & \multicolumn{4}{|c|}{ Breeding } & \multicolumn{4}{|c|}{ Consumptions } \\
\hline & & $\begin{array}{c}\text { Number } \\
\text { of }\end{array}$ & Unit & Price & Value & $\begin{array}{c}\text { Number } \\
\text { of }\end{array}$ & Unit & Price & Value \\
\hline \multicolumn{10}{|c|}{ Cost of Production Facilities } \\
\hline 1 & Seeds & 50 & $\mathrm{Kg}$ & 15.000 & 750.000 & 50 & $\mathrm{Kg}$ & 8.500 & $\begin{array}{c}425.00 \\
0\end{array}$ \\
\hline 2 & NPK Phonska & 200 & $\mathrm{Kg}$ & 2.500 & 500.000 & 200 & $\mathrm{Kg}$ & 2.500 & $\begin{array}{c}500.00 \\
0\end{array}$ \\
\hline 3 & Pesticide & 3 & Bottle & 75.000 & 225.000 & 3 & Bottle & 75.000 & $\begin{array}{c}225.00 \\
0\end{array}$ \\
\hline II. & Labor Costs & & & & & & & & \\
\hline 1 & $\begin{array}{l}\text { Land } \\
\text { preparation }\end{array}$ & 1 & На & 500.000 & 500.000 & & $\mathrm{Ha}$ & & \\
\hline 2 & Planting & 12 & HOK & 100.000 & 1.200 .000 & 12 & $\mathrm{HOK}$ & $\begin{array}{c}100.00 \\
0\end{array}$ & $\begin{array}{c}1.200 \\
000\end{array}$ \\
\hline 3 & Weeding & 12 & HOK & 100.000 & 1.200 .000 & 12 & $\mathrm{HOK}$ & $\begin{array}{c}100.00 \\
0\end{array}$ & $\begin{array}{c}1.200 \\
000\end{array}$ \\
\hline 5 & Fertilizing & 4 & $\mathrm{HOK}$ & 100.000 & 400.000 & 4 & HOK & $\begin{array}{c}100.00 \\
0\end{array}$ & $\begin{array}{c}400.00 \\
0\end{array}$ \\
\hline 6 & Irrigation & 1 & HOK & 100.000 & 100.000 & 1 & HOK & $\begin{array}{c}100.00 \\
0\end{array}$ & $\begin{array}{c}100.00 \\
0\end{array}$ \\
\hline
\end{tabular}




\begin{tabular}{|c|c|c|c|c|c|c|c|c|c|}
\hline \multirow[b]{2}{*}{$\begin{array}{l}\mathbf{N} \\
\mathbf{0}\end{array}$} & \multirow[b]{2}{*}{ Description } & \multicolumn{4}{|c|}{ Breeding } & \multicolumn{4}{|c|}{ Consumptions } \\
\hline & & $\begin{array}{c}\text { Number } \\
\text { of }\end{array}$ & Unit & Price & Value & $\begin{array}{c}\text { Number } \\
\text { of }\end{array}$ & Unit & Price & Value \\
\hline 7 & $\begin{array}{l}\text { Control of } \\
\text { HPT }\end{array}$ & 2 & $\mathrm{HOK}$ & 100.000 & 200.000 & 2 & HOK & $\begin{array}{c}100.00 \\
0\end{array}$ & $\begin{array}{c}200.00 \\
0\end{array}$ \\
\hline 8 & Harvest & 12 & $\mathrm{HOK}$ & 100.000 & 1.200 .000 & 12 & HOK & $\begin{array}{c}100.00 \\
0\end{array}$ & $\begin{array}{c}1.200 . \\
000\end{array}$ \\
\hline 9 & $\begin{array}{l}\text { Drying and } \\
\text { Threshing }\end{array}$ & 12 & $\mathrm{HOK}$ & 100.000 & 1.200 .000 & 12 & HOK & $\begin{array}{c}100.00 \\
0\end{array}$ & $\begin{array}{c}1.200 . \\
000\end{array}$ \\
\hline & $\begin{array}{l}\text { Selection and } \\
\text { Packaging }\end{array}$ & 5 & $\mathrm{HOK}$ & 100.000 & 500.000 & & & & \\
\hline \multicolumn{10}{|c|}{ III. Additional costs } \\
\hline 1 & $\begin{array}{l}\text { Administratio } \\
\mathrm{n}\end{array}$ & 2 & Time & 7.500 & 15.000 & & & & \\
\hline 2 & Label & 90 & Unit & 200 & 18.000 & & & & \\
\hline 3 & Plastic Bags & 90 & Unit & 2.500 & 225.000 & & & & \\
\hline 4 & Rent of land & 1 & $\mathrm{Ha}$ & $\begin{array}{c}1.000 .00 \\
0\end{array}$ & 1.000 .000 & 1 & $\mathrm{Ha}$ & $\begin{array}{c}1.000 .0 \\
00\end{array}$ & $\begin{array}{c}1.000 . \\
000\end{array}$ \\
\hline & $\begin{array}{l}\text { Interest at a } \\
\text { cost }\end{array}$ & & & & 369.320 & & & & $\begin{array}{c}306.00 \\
0\end{array}$ \\
\hline & $\begin{array}{c}\text { Seed } \\
\text { oduction }\end{array}$ & 1.800 & $\mathrm{Kg}$ & 12.000 & $\begin{array}{c}21.600 .00 \\
0\end{array}$ & 2.000 & $\mathrm{Kg}$ & 6.500 & $\begin{array}{l}13.000 \\
.000\end{array}$ \\
\hline V. & Total costs & & & & 9.602 .320 & & & & $\begin{array}{c}7.956 . \\
000\end{array}$ \\
\hline & Reception & & & & $\begin{array}{c}11.997 .68 \\
0\end{array}$ & & & & $\begin{array}{c}5.044 . \\
000\end{array}$ \\
\hline & I. $\mathrm{R} / \mathrm{C}$ & & & & 2,25 & & & & 1,63 \\
\hline & II. $\mathrm{B} / \mathrm{C}$ & & & & 1,25 & & & & 0,63 \\
\hline
\end{tabular}

The results of the analysis of soybean breeding business in the West Coast and East Coast of South Sulawesi show that breeder farmers are feasible to be developed and profitable. At the West Coast $\mathrm{R} / \mathrm{C}=2.33$ and $\mathrm{B} / \mathrm{C}=1.33$, while on the East Coast $\mathrm{R} / \mathrm{C}=2.25$ and $\mathrm{B} / \mathrm{C}=$ 1.25. As for farmers consumption is still feasible to be developed on the West Coast with $\mathrm{R} / \mathrm{C}$ $=1.72$ and the East Coast with $\mathrm{R} / \mathrm{C}=1.63$, but less profitable because on the West Coast $\mathrm{B} / \mathrm{C}$ $=0.72$ and on the East Coast $\mathrm{B} / \mathrm{C}=0.63$.

\subsection{Social Network Analysis}

Soybean breeders, which are farmer groups both on the West Coast and East Coast of South Sulawesi, are social capital that can distribute soybean seeds. Soybean breeders on the West Coast are spread in Maros, Pangkep, Pinrang, Gowa, Takalar and Jeneponto districts with an average productivity of 1.45 to 1.6 tons/ha. Whereas soybean breeders on the East Coast are spread in Wajo, Bone and Soppeng districts with an average productivity of $1.8-2.0$ tons/ha. Soybean breeders usually only breed soybeans when there is a project from the Government, this happens because the networks between farmer groups on the West and East Coast are not connected. Future networks of farmer groups should be empowered as distributors of soybean seeds so that soybean seeds can be available throughout the year.

Table 3. Analysis of distance distribution of soybeans on the West and East Coast based on breeder locations

\begin{tabular}{cccccccc}
\hline \multicolumn{2}{c}{ Distance (km) } & \multicolumn{3}{c}{ Maros } & \multicolumn{2}{c}{ Takalar } \\
\cline { 3 - 7 } & & Jenetaesa & Leang-leang & Toddolimae & Toddopulia & Mannongkoki & Sawakong \\
\hline \multirow{2}{*}{ Soppeng } & Salokaraja & 118,457 & 122,190 & 142,759 & 143,206 & 181,997 & 187,134 \\
& Attangsalo & 133,266 & 137,823 & 157,159 & 157,536 & 196,191 & 201,216 \\
& Panincong & 129,281 & 132,964 & 153,365 & 153,988 & 192,409 & 198,254
\end{tabular}




\begin{tabular}{|c|c|c|c|c|c|c|c|}
\hline \multirow{2}{*}{\multicolumn{2}{|c|}{ Distance (km) }} & \multicolumn{4}{|c|}{ Maros } & \multicolumn{2}{|c|}{ Takalar } \\
\hline & & Jenetaesa & Leang-leang & Toddolimae & Toddopulia & Mannongkoki & Sawakong \\
\hline \multirow{3}{*}{ Bone } & Liliriawang & 129,039 & 133,045 & 153,454 & 154,564 & 193,202 & 198,057 \\
\hline & Mattampawalie & 55,483 & 59,398 & 79,903 & 80,510 & 119,468 & 124,428 \\
\hline & Corawalie & 158,142 & 162,239 & 182,760 & 183,488 & 221,646 & 227,842 \\
\hline
\end{tabular}

Distribution from the West Coast to the East Coast of South Sulawesi or vice versa can be done between farmer groups that are spread in villages in one district. Table 3 shows that for distribution from the West Coast to the East Coast or vice versa it is best to go through the closest path, namely the soybean breeder in Mattampawalie or Salokaraja with the soybean breeder in Jenetaesa. However, a network map (sociogram) between breeders as shown in figure 1 can be a reference in conducting analysis especially in terms of trust and familiarity between farmer groups between one district and another district.

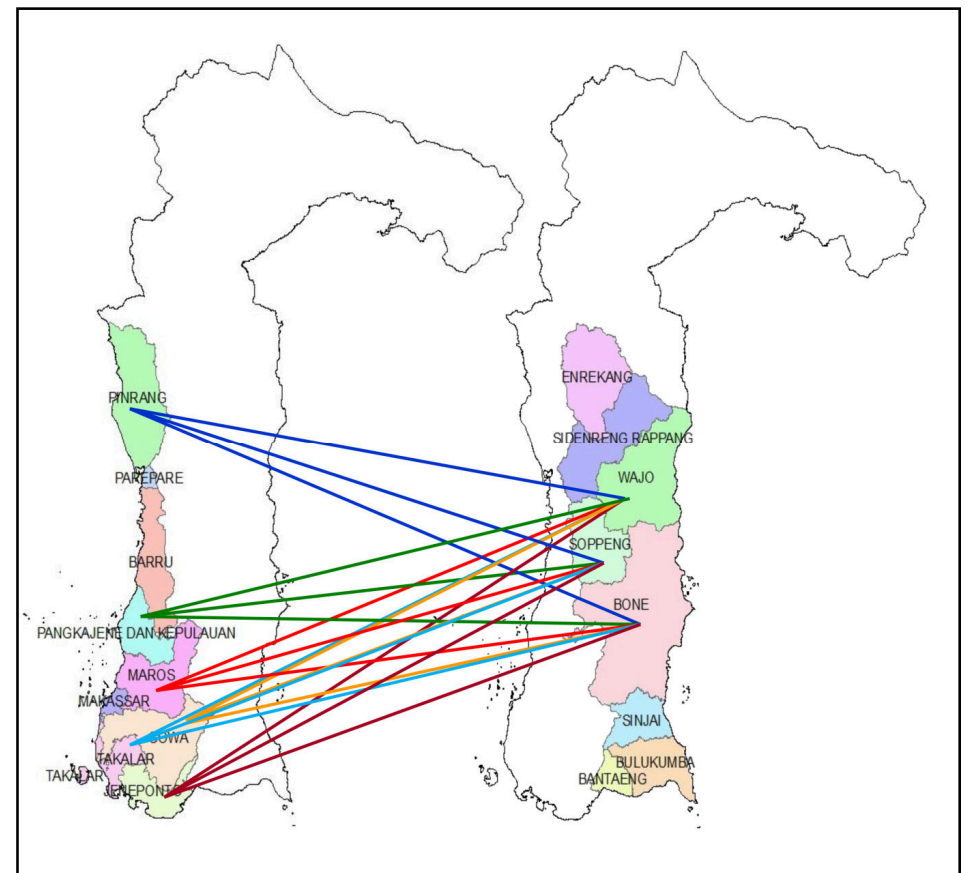

Fig. 1. Sociogram of West Coast and East Coast Soybean Breeders

\subsection{Climate Analysis}

Growth and production of soybean plants is strongly influenced by climatic conditions, especially on water availability [10]-[11]. Rainfall is very important in soybean plants which are cultivated during the dry season [12]. Fulfillment of soybean crop water needs in the range of 450-700 $\mathrm{mm}$ during the growth period has a very important role in soybean productivity [13].

Soybean in Indonesia is generally planted during the dry season where rainfall is below 50 $\mathrm{mm}$, or planted after lowland rice, that is when there is a lack of ground water and low rainfall. Planting after lowland rice (the first planting season) can be done both in rainfed and irrigated areas, but if it has entered the second planting season, then the planting area can only be done in irrigated areas [14]. 
Based on spatial data of normal monthly rainfall for 30 years (1981-2010) [15]-[16], South Sulawesi has a unique climate that coexists where if the West Coast is the dry season then the East Coast is the rainy season and vice versa. The dry season on the West Coast of South Sulawesi starts in April (Figure 2) to October (Figure 3), and the East Coast of South Sulawesi in August (Figure 4) to February (Figure 5).

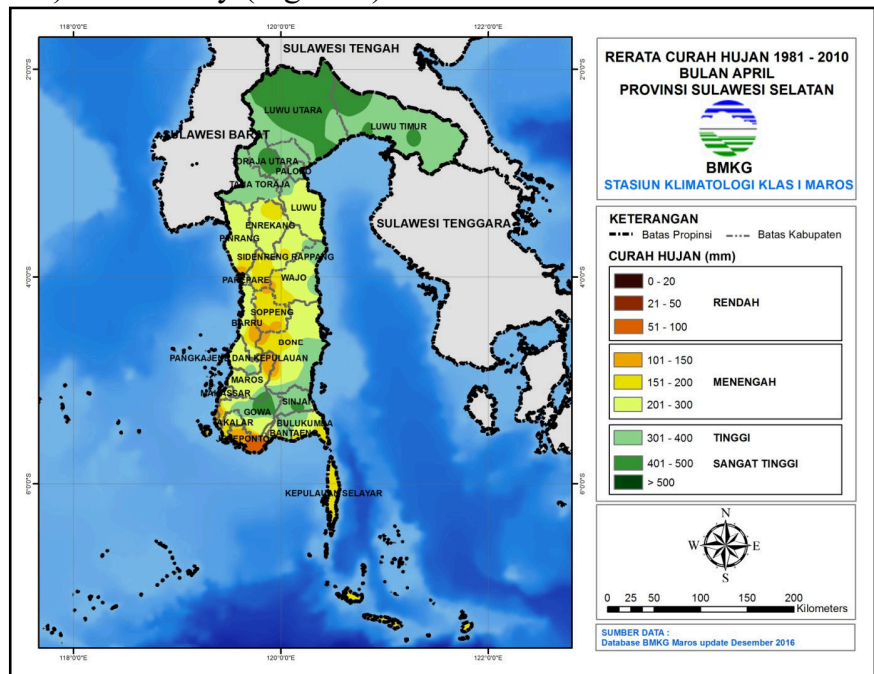

Fig. 2. Average Rainfall in April of 1981-2010

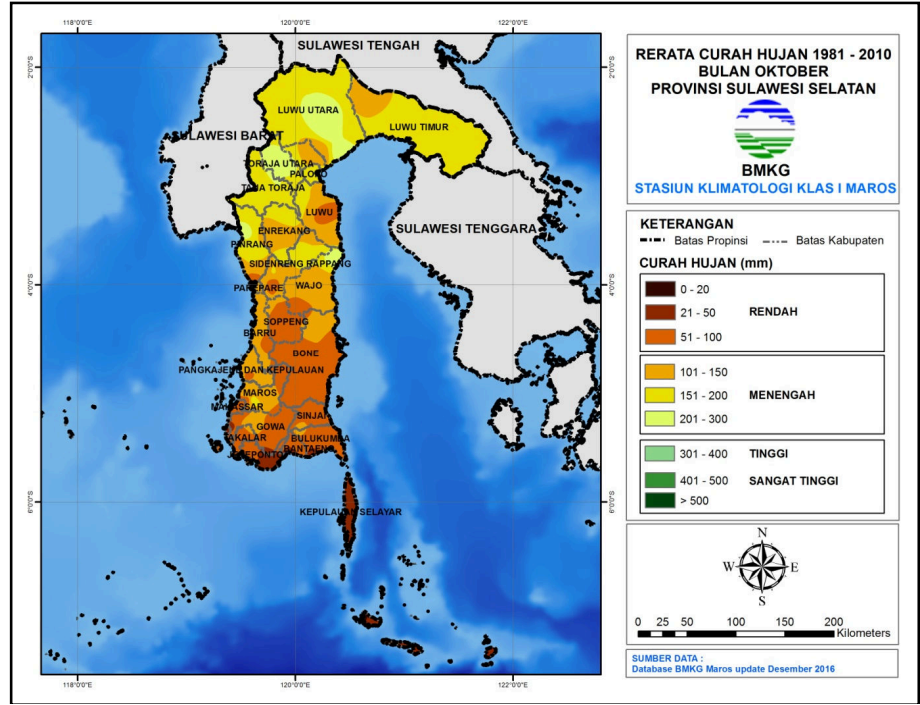

Fig. 3. Average Rainfall in October of 1981-2010 


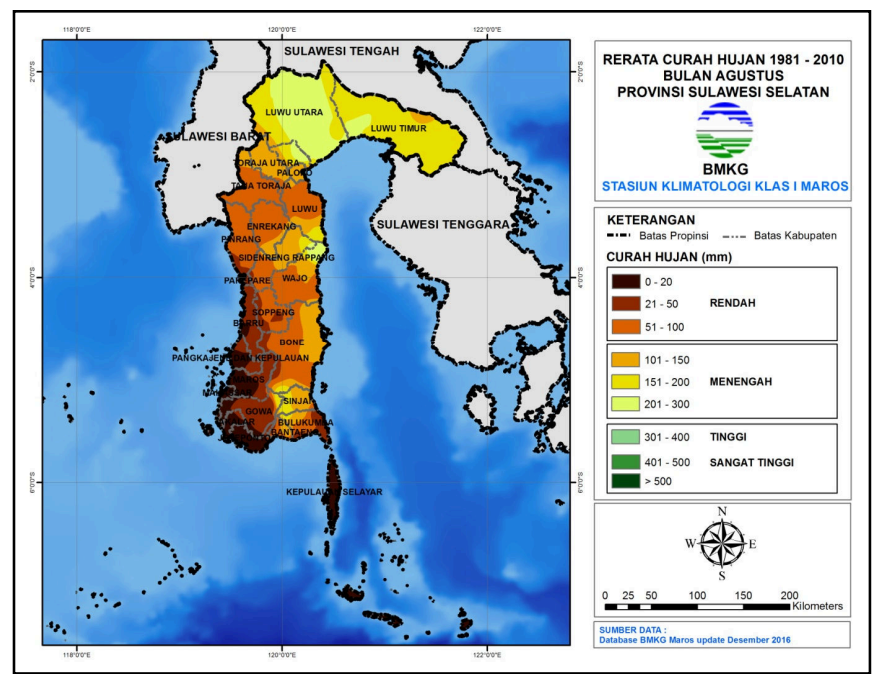

Fig. 4. Average Rainfall in August of 1981-2010

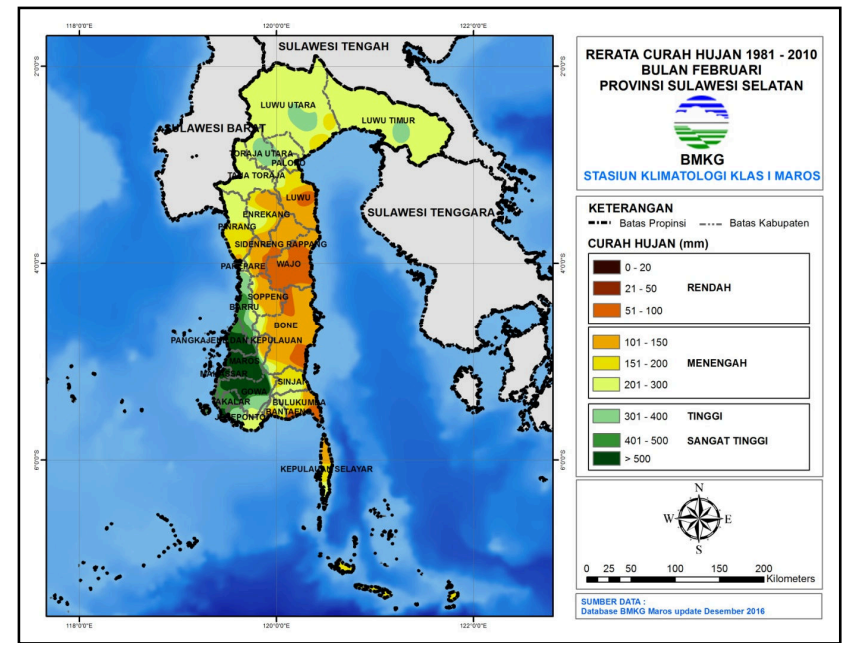

Fig. 5. Average Rainfall in February of 1981-2010

Map of monthly rainfall over 30 years (1981-2010) shown by figures 2 to 5 , shows that soybean seeds planted on the West Coast in April that are harvested in mid-July and packaging until early August, can be subsequently planted in the second planting season in August and can also be circulated to the East Coast which will plant in August. Second crop yields on the West Coast at the end of October can be circulated to the East Coast which will be planted in December.

Soybean seeds planted on the East Coast in August and harvested at the end of October will be used as seeds for further planting on the East Coast. Seeds harvested at the end of October on the East Coast are not circulated to the West Coast, because in November the West Coast has entered the rainy season. Furthermore, soybean planting in early December which is harvested at the end of February on the East Coast can be circulated to the West Coast for the 
April planting season, and not planted on the East Coast, because in March the East Coast has entered the rainy season.

\section{Conclusion}

Soybean business is more profitable to be cultivated in the East Coast of South Sulawesi with an $\mathrm{R} / \mathrm{C}$ ratio of 2.25 and 1.63 , while the $\mathrm{B} / \mathrm{C}$ ratio is 1.25 and 0.63 for each breeder and consumption farmer, compared to the Coast West for breeders and consumption farmers each have an $\mathrm{R} / \mathrm{C}$ ratio of 2.33 and 1.33 , while the $\mathrm{B} / \mathrm{C}$ ratio of 1.72 and 0.72 .Soybean farmer groups are a potential social network in the supply of seeds and the sustainability of soybean production in South Sulawesi. The unique climate of South Sulawesi with the alternating dry and rainy seasons between the West and East coasts enables continuous soybean production throughout the year.

\section{REFERENCES}

[1] Central Bureau of Statistics, "Food Crops", http://www.bps.go.id/ tnmnpgn.php. Accessed September 2, 2019.

[2] H Gunadi and M. Djunaidy, "Drip Irrigation and Seed Priming Treatment on Soybeans during the Dry Season in Maros District, South Sulawesi Province, Indonesia", International Journal of Innovative Science and Research Technology, Volume 4, Issue 2, pp. 500-503, 2019.

[3] H. A. Elkheir, Y. Musa, M. Muslimin, R. Sjahril, M. Riadi, and H. Gunadi, "Harvest index and yield components of aerobic rice (Oryza sativa) under effect of water, varieties and seed priming", IOP Conf. Series: Earth and Environmental Science 157 (2018)

[4] H. Gunadi, Kaimuddin, S. Baja, and M. Riadi, "Evaluation of the CropSyst Model on Soybean (Glycine max L.) in the Tropics", International Journal of Environmental \& Agriculture Research, Volume 4, Issue 6, pp. 41-45, 2018.

[5] D. Ç. Taşdemir, A. D. Bahar, and F. Çayırağası, "A Study on Social Capital Concept, Development and Importance”, International Journal of Management Science and Business Administration Vol. 4, No. 1, pp 52-56, 2017.

[6] G. Cofré-Bravoa, L. Klerkx, and A. Engler, "Combinations of bonding, bridging, and linking social capital for farm innovation: How farmers configure different support networks", Journal of Rural Studies, Vol. 69, pp 53-64, 2019.

[7] D. S. N. Oetama, E. Kernalis, and A. Arby, "Analysis of Rice and Soybean Farming in Berbak Sub-district, East Tanjung Jabung District", Sosio Economics of Business, Volume 17, Nomor 2, pp 72-81, 2014.

[8] I. K. Suardana, I. G. A. A. Ambarawati, and I. D. P. O. Suardi, "Analysis of Farming for Soybean Breeding (Case in Subak Kusamba, Dawan Sub-district, Klungkung District)", Agribusiness and Agro Tourism Journal, Volume 5, Nomor 1, pp 1-9, 2016.

[9] D. C. Aidoo and C. K. Freeman, "Agricultural Informational Flow in Informal Communication Networks of Farmers in Ghana", Journal of Development and Communication Studies, Volume 4, Nomor 2, pp 443-453, 2016. 
[10] A. J. Zanon, N. A. Streck, and P. Grassini, "Climate and Management Factors Influence Soybean Yield Potential in A Subtropical Environment", Agronomy Journal, Volume108, Nomor 4, pp 1447-1454, 2016.

[11] L. C. Reis, C. M. S. Silva, M. H. C. Spyrides, and B. G. Bezerra, "Climate Trends in Bom Jesus, Soybean Production Region in Piaui", Revista Geama,Volume 3, Nomor 4, pp 196-200, 2017.

[12] V. Mandić, Z. Bijelić, V. Krnjaja, A. Simić, D. R. Muslić, V. Dragičević, and V. Petričević, "The Rainfall Use Efficiency and Soybean Grain Yield Under Rainfed Conditions in Vojvodina", Biotechnology in Animal Husbandry, Volume 33, Nomor 4, pp 475-486, 2017

[13] P. Steduto, T. C. Hsiao, E. Fereres, and D. Raes, "Crop Yield Response to Water, FAO Irrigation and Drainage Paper", FAO Publications, Rome, Italy, 500 pp. 2012.

[14] R. Wirosoedarmo, F. Rizqiyah, Sudarto and E. Handayanto, "Land Suitability Evaluation for Soybean Using Geographic Information System in Malang District, Indonesia", International Journal of Applied Engineering Research, Volume 10, Nomor 16, pp 36546-36555, 2015.

[15] N. Bhargava, R. Bhargava, P. S. Tanwar, and A. Sharma, "Rainfall Spatial Analysis Using GIS", International Journal of Advanced Research in Computer and Communication Engineering, Volume 2 Nomor 5, pp 2197-2200, 2013.

[16] K. D. Marco, V. R. M. Dias, R. Dallacort, E. D. L. Alves, R. C. T. Tieppo, D. V. Arajo, and J. D. Barbieri, "Spatial Variability of The Ten-Day Rainfall in The Months in Which The Sowing of Soybean And Winter Corn Begins in The State Of Mato Grosso", Cientifica Jaboticabal, Volume 44, Nomor 4, pp 477-484, 2016. 